Relations industrielles

Industrial Relations

\title{
Conciliation Procedures in Alberta
}

\section{Norman F. Dufty}

Volume 27, numéro 4, 1972

URI : https://id.erudit.org/iderudit/028339ar

DOI : https://doi.org/10.7202/028339ar

Aller au sommaire du numéro

\section{Éditeur(s)}

Département des relations industrielles de l'Université Laval

\section{ISSN}

0034-379X (imprimé)

1703-8138 (numérique)

Découvrir la revue

\section{Citer cet article}

Dufty, N. F. (1972). Conciliation Procedures in Alberta. Relations industrielles / Industrial Relations, 27(4), 775-781. https://doi.org/10.7202/028339ar

Tous droits réservés @ Département des relations industrielles de l'Université Laval, 1972
Ce document est protégé par la loi sur le droit d'auteur. L'utilisation des services d'Érudit (y compris la reproduction) est assujettie à sa politique d'utilisation que vous pouvez consulter en ligne.

https://apropos.erudit.org/fr/usagers/politique-dutilisation/ 
ventions collectives. Sauf au cours de deux guerres mondiales, en effet, les pouvoirs publics n'ont pas jugé opportun d'imposer dans les divers règlements ou ordonnances qu'ils ont adoptés concernant les salaires, leur ajustement automatique, suivant les fluctuations de la valeur du dollar.

La détermination des traitements est certes au Canada, comme ailleurs, la partie des négociations collectives qui fait naître entre le patronat et les syndicats, les plus vives oppositions. Conscients de l'importance de ce sujet, ces groupements ont jusqu'à maintenant préféré aborder cette matière, dans un esprit essentiellement pragmatique et se méfient généralement de tout mode de fixation des traitements qui peut leur sembler trop systématique. A cet égard, les syndicats eux-mêmes, qui ont pourtant, à l'occasion, favorisé l'insertion des clauses d'indexation des salaires dans les conventions collectives, ont par ailleurs bien souvent fait montre de réticence, en ce qui concerne ce mode de fixation des traitements. Leur attitude leur est peut-être dictée par leur crainte que les augmentations automatiques accordées aux employés ne soient invoquées lors des négociations collectives pour les convaincre de leur bien-être relatif et les décourager de toute tentative d'obtenir des gains plus considérables.

\title{
CONCILIATION PROCEDURES IN ALBERTA
}

\author{
Norman F. Dufty
}

Cunningham has recently reviewed the effects of changes in the conciliation procedures in several provinces ${ }^{1}$ and it is the purpose of this paper to examine the results of the 1968 changes to Alberta Labour Act relating to the appointment of conciliation boards ${ }^{2}$. Prior to these changes the failure of parties to collective bargaining negotiations to reach agreement unaided or with the assistance of a conciliation commissioner resulted in the appointment of a conciliation board. As the Act now stands a conciliation commissioner may recommend to the Minister that a conciliation board be appointed or not. If the Minister agrees that no board should be appointed then the recommendations of the conciliation

* DufFy, Normand F., Dean of Commerce and Social Sciences, Western Australian Institute of Technology, Perth, Australia.

1 W. B. Cunningham, «Conciliation: The End of Compulsory Boards », Relations Industrielles, 25, 1970, 62-79.

2 The writer derived considerable benefit from discussions with Professors J. D. Muir and A. Melnyk of the University of Alberta and Mr. H. J. H. Libke and T. T. Grothen, conciliation commissioners on the staff of the Board of Industrial Relations of the Province of Alberta. They bear no blame for this paper's inadequacies or inaccuracies. He is also grateful to Mr. French, deputy chairman of the Board, for granting access to the files and permission to use the data in aggregate jobs. 
commissioner have the same effect and force as the award of a conciliation board (Section 86).

\section{COMPARISON OF ELAPSED TIMES}

There have been many arguments in the literature against the use of compulsory conciliation. Some of these, such as the finite cost of the process $^{3}$ and the shortage of suitable conciliators ${ }^{4}$, have verged on the trivial. Others have consisted mainly of vague and largely unsubstantiated comments about the "damage » done by the process to collective bargaining ${ }^{5}$ and the fact that compulsory conciliation « distracts $\gg$ the parties from the main task, reaching a collective agreement ${ }^{6}$. However, in terms of objective factors, there is little doubt that the compulsory conciliation process does lead to lengthy and largely unnecessary delays ${ }^{7}$. In order to examine the effect of the revised procedures on the time taken for the total process, including the voting on the recommendations or awards and post-conciliation bargaining, an investigation was made of 50 disputes which were handled by conciliation boards in 1968-1969. These were compared to a similar number which were dealt with in 1970 by conciliation commissioner's recommendations. In order to keep one factor constant, the comparison was confined to disputes in the private sector. The parties are under no obligation to notify the Board of Industrial Relations of the date of the signing of the collective agreement after the steps required under the Alberta Labour Act are complete. However, in many cases they continued to use the services of a conciliation commissioner on a completely voluntary basis in the post-conciliation bargaining

3 F.R. Anton, Government Supervised Strike Votes, (Toronto : $\mathrm{CCH}$ Canadian, 1962), p. 123.

4 H. A. Logan, State Intervention and Assistance in Collective Bargaining, (Toronto: University of Toronto Press, 1956), pp. 91-93.

5 H. D. Woons and S. Ostry, Labour Policy and Labour Economics in Canada, (Toronto: Macmillan, 1962), p. 273 and H.D. Woods, "Canadian Collective Bargaining and Dispute Settlement Policy : An Appraisal $»$, Canadian Journal of Economics and Political Science, 21, 1955, 453.

6 Anton, op. cit., p. 123 ; D.J.M. Brown, Interest Arbitration, (Ottawa : Queen's Printer, 1968), p. 242 ; and Woods and Ostry, op. cit., p. 185.

7 Brown, op. cit., p. 241 ; S. JAMIESON, «Labour Dispute Settlement in the Construction Industry of British Columbia, 1948-1954», in H. D. Woons (ed.), Patterns of Dispute Settlement in Five Canadian Industries, (Montreal : Industrial Relations Centre, McGill University, 1958), p. 249 ; C. KIDD, "Union View of Government in Labour Relations », in F. BaIRstow (ed.), The Role of Government in Industrial Relations, (Montreal : Industrial Relations Centre McGill University, 1960), p. 73 ; LogaN, op. cit., p. 91 ; M. K. Oliver, «Third Patry Intervention in the Quebec Primary Textile Industrly, 1944-1952», in Woods (ed.),op. cit., pp. 312 314 ; W.G. PHILlips, « Government Conciliation in Labour Disputes : Some Recent Experiences in Ontario », Canadian Journal of Economics and Political Science, 22, 1956, 525, Woods in BaIRSTow (ed.), op. cit., p. 69. 
phase and data were sometimes available on final settlement dates. All the information is shown in Table 1 and it can be seen from this that the number of cases on which information is available on the post-conciliation phase is limited. Assuming that the time lapse data on post-conciliation negotiations is representative, the difference between the two methods in terms of elapsed time is considerable. Procedures based on conciliation board awards take 2.2 to 2.3 times as long as those based on conciliation commissioners' recommendations, depending on whether the means or the medians are used as a basis for comparison.

\section{TABLE I}

Time Lapse Data on Dispute Handling by Conciliation Boards (1968-1969) and by Conciliation Commissioners * (1970), Private Sector, Alberta (Calendar Days).

\begin{tabular}{|c|c|c|c|c|c|c|}
\hline \multirow[t]{2}{*}{ Dispute Phase } & \multicolumn{2}{|c|}{$\begin{array}{l}\text { Conciliation } \\
\text { Sample }\end{array}$} & \multirow{2}{*}{$\begin{array}{l}\text { Board } \\
\text { Median }\end{array}$} & \multicolumn{3}{|c|}{$\begin{array}{l}\text { Conciliation Commissioner } \\
\text { Sample }\end{array}$} \\
\hline & Size & Mean & & Size & Mean & Median \\
\hline $\begin{array}{l}\text { Conciliation and Recom- } \\
\text { mendation Where Appli- } \\
\text { cable** }\end{array}$ & 50 & 42.2 & 34 & 50 & 39.6 & 31 \\
\hline $\begin{array}{l}\text { Appointment of Conciliation } \\
\text { Board }\end{array}$ & 50 & 56.8 & 51 & Not & applic & able \\
\hline $\begin{array}{l}\text { Conciliation Board Re- } \\
\text { commendations }\end{array}$ & 50 & 48.5 & 42 & Not & applic & able \\
\hline $\begin{array}{l}\text { Voting on Recommen- } \\
\text { dations }\end{array}$ & 40 & 14.3 & 13 & 50 & 18.5 & 18 \\
\hline Final Negotiations & 12 & 28.0 & 26 & 22 & 27.3 & 24 \\
\hline TOTAL & - & 189.8 & 166 & - & 85.4 & 73 \\
\hline
\end{tabular}

\section{COMPARISON OF EFFICIENCIES}

The data reported above establish quite clearly that the use of conciliation commissioners' recommendations rather than conciliation board awards is much less time-consuming. The question of whether or not this method is more efficient is very difficult to answer. One major difficulty is deciding on a measure of efficiency. If one accepts the somewhat peculiar position that work stoppages are constructive social phenomena ${ }^{8}$

* Cases in which the conciliation commissioners recommendations have the effect and force of a conciliation board award.

** When a dispute is to be handled by a conciliation board, a conciliation commissioner may or may not make a recommendation. If he feels that a recommendation will serve no useful purpose, he does not make one. 
Results of Conciliation Board Awards (1968-1969) and Conciliation

Commissioners' Recommendations (1969-1970), Alberta. (Percentages)

\begin{tabular}{|c|c|c|c|c|c|c|c|}
\hline \multirow{2}{*}{$\begin{array}{l}\text { Conciliation } \\
\text { Board Award }\end{array}$} & \multicolumn{2}{|c|}{ Results of Voting } & \multirow[b]{2}{*}{$\begin{array}{l}\text { Number } \\
\text { of Cases }\end{array}$} & \multirow[b]{2}{*}{$\begin{array}{l}\text { Percentage } \\
\text { Accepted } *\end{array}$} & \multirow{2}{*}{$\begin{array}{l}\text { Strike } \\
\text { Votes }\end{array}$} & & \multirow{2}{*}{ Strikes } \\
\hline & Employer & Employees & & & & $\begin{array}{c}\text { Strikes } \\
(\% \text { Votes })\end{array}$ & \\
\hline Unanimous & \multicolumn{2}{|c|}{ All Awards } & 40 & 20.0 & 50.0 & 25.0 & 12.5 \\
\hline Union Dissent & \multirow{2}{*}{\multicolumn{2}{|c|}{ 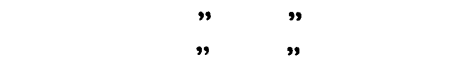 }} & 26 & 7.7 & 63.1 & 50.0 & 30.7 \\
\hline Employer Dissent & & & 8 & 0 & 75.0 & 16.7 & 12.5 \\
\hline All Awards & Affirmative & Affirmative & 10 & 100.0 & 0 & 0 & 0 \\
\hline$" \quad "$ & Negative & Negative & 21 & 0 & 71.6 & 40.0 & 28.6 \\
\hline$" \quad "$ & Affirmative & Negative & 32 & 0 & 65.8 & 33.3 & 25.0 \\
\hline$"$ & Negative & Affirmative & 9 & 0 & 66.7 & 16.7 & 11.1 \\
\hline$" \quad "$ & \multicolumn{2}{|c|}{ All Awards } & 74 & 13.5 & 56.9 & 33.3 & 18.9 \\
\hline Conciliation & Affirmative & Affirmative & 20 & 100.0 & 0 & 0 & 0 \\
\hline Commissioners' & Negative & Negative & 37 & 0 & 32.4 & 16.7 & 5.4 \\
\hline \multirow[t]{3}{*}{ Recommendations } & Affirmative & Negative & 35 & 0 & 63.0 & 13.6 & 8.6 \\
\hline & Negative & Affirmative & 14 & 0 & 50.0 & 28.5 & 14.3 \\
\hline & \multicolumn{2}{|c|}{ All Recommendations } & 106 & 18.9 & 38.7 & 17.1 & 6.6 \\
\hline
\end{tabular}

* Received an affirmative vote from both emplovers and employees. 
then, by reductio ad absurdum, one might conclude that efficiency should be positively related to the number of strikes. However, accepting the more conventional view, that a procedure which reduces strikes is more efficient than one which does not, the percentage of disputes resulting in strike action can be taken as one measure of success and efficiency inversely related to it. Another measure which may be used, again with an inverse relationship, is the percentage of disputes which are taken as far as a strike vote and also the percentage of these cases which actually result in a work stoppage. Finally, as both employers and employees vote on conciliation board awards and on the recommendation of conciliation commissioners, the percentage of cases in which both parties vote in the affirmative may also be taken as an efficiency measure. Data on 74 conciliation board cases in the 1968-1969 period were collected and compared to the data on 106 cases in the 1969-1970 period which were dealt with by conciliation commissioners' recommendations. The results are shown in Table 2.

As might be anticipated, when a conciliation board award was unanimous the probability of it receiving an affirmative vote from both employers and employees was significantly higher $(p<.05)$ than if either board made a majority award. Similarly, the percentage of disputes resulting in strikes was significantly lower $(p<.05)$. There were no significant differences on other measures. When both sides voted affirmatively the award became binding and no strike votes or strikes occurred; there were no significant differences between the other voting patterns. Data on the voting behavior on conciliation commissioners' recommendations also shown in Table 2 reveal no significant differences between voting patterns on any measure after excluding the dual affirmative votes which result in binding agreements. When the two methods are compared conciliation commissioners' recommendations are superior to conciliation board awards on all measures although only the difference in the percentage of disputes resulting in strike action is significant $(p<.02)$.

Owing to difficulties in making meaningful comparisons the above results cannot be taken as being conclusive. The comparison made in Table 2 uses over-lapping time periods and an objection may be raised on these grounds. If we take conciliation board awards for 1968 and compare them to conciliation commissioners' recommendations for 1969 it could be pointed out that the board awards contained a much larger percentage of disputes in the public sector than those based on conciliation commissioners' recommendations. If the comparison is confined to the private sector ${ }^{9}$ then it could be said that economic conditions in 1968

8 BRown, op. cit., p. 252 ;; S. JAMIESON, «Industrial Relations and Government Policy », Canadian Journal of Economics and Political Science ,19, 1951, 35-36; Woods in Bairstow (ed.), op. cit., p. 69 ; and Woods and Ostry, op. cit., p. 194.

9 There were insufficient cases from the public sector handled by conciliation commissioners' recommendations to make any meaningful comparisons in this area alone. 
differed sufficiently from those in 1969 to invalidate the comparison. Even if the comparison is made in the same year in the private sector alone it could be argued that the more refractory disputes were sent to conciliation boards and the less refractory ones made the subject of conciliation commissioners' recommendations. All the above comparisons were made and in all cases the conciliation board awards were less successful on the measures used than the recommendations of conciliation commissioners. Owing to the smaller cell sizes, there were no significant differences at the $5 \%$ level or better. If the comparisons made in Table 2 are repeated after excluding all public sector disputes the picture remains unaltered except the difference in the percentage of cases going to strike action is significant at the $1 \%$ level, not $2 \%$ as before. Nevertheless, even though the evidence cannot be taken as conclusive, due to the reasons outlined above, it can certainly be taken as strongly suggestive.

The above results are not altogether surprising. Most of the theoretical work done on the conciliation process emphasises, inter alia, the role of the conciliator as a confidential communication channel between the parties involved in the negotiations ${ }^{10}$. In conciliation board proceedings the parties have representatives and the board is chaired by an individual whose full-time job is not conciliation and who may not be familiar with the industry or the people involved. This remoteness from the dispute is emphasised by the fact that only $20 \%$ of unanimous awards received an affirmative vote from both employers and employees (see Table 2). On the other hand, the conciliation commssioner is working directly with the parties, he enters the dispute at an earlier stage than a conciliation board, he is likely to know the parties well, and his fulltime job is conciliation. On a priori grounds, therefore, it is not unreasonable to assume that he would establish better communications than a conciliation board in a situation where the next step is continued bipartite bargaining possibly followed by strike action. The conciliation commissioner's deeper knowledge of the parties and the dispute are also likely to enable to give a superior performance to that of a conciliation board in the persuasive phase of the conciliation process ${ }^{11}$ under the

10 A. Douglas, Industrial Peacemaking, (New York: Columbia University Press, 1962), p. 24 ; J. Podell and W. M. KNAPP, «The Effect of Mediation on the Perceived Firmness of the Opponent 》, Journal of Conflict Resolution, 13, 1969, 511520 ; C. M. ReHmus, «Mediation and Conciliation》, Labor Law Journal, 4, 1953, 141-144; C. M. Stevens, Strategy and Collective Bargaining Negotiations, (New York : McGraw Hill, 1963), p. 99 ; and R. E. Walton and R. B. McKersie, $A$ Behavioral Theory of Labor Negociations, (New York: McGraw Hill, 1965), pp. 119 and 159.

11 H.G. Lovell, «The Pressure Lever in Mediation», Industrial and Labor Relations Review, 5, 1952/1953, 119-127 ; T. Schelling, "The Strategies of' Conflict : A Prospectus 》, Journal of Conflict Resolution, 2, 1958, 236 ; STEVENS, op. cit., p. 129 ; and R. WILson, "Conciliation Officers' Techniques the Settlement of Labour Disputes », a paper prepared for the 18th Conference of the Canadian Association of Administrators of Labour Legislation, Quebec, September, 1959. 
same conditions so far as the stage of the dispute is concerned. Of course, it could be argued that the conciliation commissioner has the opportunity to function as a communication channel and a persuader in the earlier phase of the dispute in all cases. But compulsory conciliation followed by a tripartite board is a distinctly different situation from compulsory conciliation followed by the conciliator's recommendations on which both parties vote.

\section{CONCLUSION}

On the basis of the data presented here the alternative procedure introduced by the 1968 amendment to the Alberta Labour Act, conciliation commissioner's recommendations having the force and effect of a conciliation board award, is considerably less time-consuming than the use of conciliation boards. Although conclusive proof of superiority in any scientific sense is not possible, the data suggest that the shorter procedure is also more effective. There are $a$ priori reasons to support this. This investigation supports Cunningham's conclusions ${ }^{12}$ and, to some extent, the recommendations of the Task Force on Labour Relations ${ }^{13}$, that conciliation boards should be abolished or made voluntary. However, it may be preferable to allow conciliation boards to be appointed at the Minister's discretion when, after seeking the advice of the Board of Industrial Relations, he feels that the one or both of the parties have not the competence to conduct responsible collective bargaining negotiations. Such occurrences would be rare.

12 CunNinghaM, loc. cit., 79.

13 Canadian Industrial Relations, (Ottawa : Queen's Printer, 1969), p. 169.

\section{LE DROIT DISCIPLINAIRE DANS LA FONCTION PUBLIQUE}

L'article publié dans le numéro précédent, volume 27 , numéro 3 , page 454 , attribué à Patrice Garant a été préparé par Patrice Garant et Marcel Morin. 